\title{
The Spontaneous Release of a High-Molecular-Weight Aggregate Containing Immunoglobulin G From the Surface of Ehrlich Ascites Tumor Cells
}

\author{
Harry G. Rittenhouse, Diane Ar, Matthew D. Lynn, and David K. Denholm \\ Department of Biological Chemistry, The University of Michigan, Ann Arbor, Michigan \\ 48109
}

The spontaneous release of tumor cell antigens from the cell surface into the circulation has been proposed as a mechanism whereby tumors may escape the immune response of the host. In this study we have found that Ehrlich ascites tumor cells after removal from the host (mouse) spontaneously release signif icant amounts of cell surface components during incubation for $1 \mathrm{~h}$ in cold isotonic buffer. Immunodiffusion studies revealed that immunoglobulin G (IgG) and a complement component (C3) are included in this spontaneously released material. These surface-bound humoral immune components are apparently released in the form of a high-molecular-weight aggregate (cell coat particle) as shown by ultracentrifugation and ultrafiltration experiments. Precipitation of IgG from the cell coat particle preparation with antibodies directed against mouse IgG followed by detergent gel electrophoresis of the immune precipitate revealed five major bands in addition to the heavy and light chains of IgG. These results suggest that host IgG is tightly bound to several other components at the cell surface, perhaps in the form of immune complexes.

IgG is localized on the tumor cell surface in a highly heterogeneous pattern with the appearance of patches and caps in some cells as shown by immunofluorescence analysis. The possibility that humoral immune components bind to the tumor cell surface and result in the shedding of high-molecular-weight aggregates of cell surface antigens into extracellular fluids is discussed.

Key words: tumor cell antigens, surface-bound humoral immune components, cell coat, immune complexes

The release or "shedding" of cell surface antigens is thought to play an important role in tumor growth and escape from the immune response of the host [1-3]. Numerous studies in animal tumor experimental systems $[4,5]$ and in human cancer patients [6]

Harry G. Rittenhouse is presently at Mental Health Research Institute, The University of Michigan. Ann Arbor, MI 48109.

Received April 28, 1978; accepted August 8, 1978. 
have revealed the presence of blocking factors in the sera of tumor-bearing hosts. It is presently thought that blocking factors may include free antigen $[5,7]$ and soluble immune complexes of tumor antigens and antibodies [4]. Human melanoma cells grown in vitro have been shown to spontaneously release tumor-associated antigens into the culture medium $[8,9]$.

In a previous study, we reported that a significant amount of the surface-labeled proteins (lactoperoxidase method) of Ehrlich ascites tumor cells grown in vivo (SwissWebster mice) were spontaneously released into isotonic buffer at $4^{\circ} \mathrm{C}$ for $60 \mathrm{~min}[10]$. In marked contrast, mild isotonic buffer treatment of tumor cells maintained in vitro resulted in the release of less than $1 \%$ of the protein shed from tumor cells grown in vivo [10]. The working hypothesis to explain the above observation is that the host's immune response to the tumor is responsible for the facile shedding of tumor cell surface components. Characterization of the spontaneously released material revealed that this fraction (referred to as cell coat fraction) was comprised largely of glycoproteins and glycosaminoglycans. It is unlikely that the cell coat fraction represents plasma membrane vesicles, since markers for plasma membrane including $\left(\mathrm{Na}^{+}, \mathrm{K}^{+}\right)$-ATPase, cholesterol, and sialic acid were markedly reduced or absent [10]. In the present study we have investigated the possibility that the material spontaneously shed from Ehrlich ascites tumor cells (cell coat fraction) may be derived from host immune components complexed with tumor cell proteins at the cell surface.

\section{METHODS}

\section{Cells}

Ehrlich ascites tumor cells were maintained by serial transplantation of $0.2 \mathrm{ml}$ of the ascites cell suspension into the peritoneal cavity of male Swiss albino mice. Tumor cells were harvested by collecting the ascites fluid in cold Dulbecco's phosphate-buffered saline (pH 7.4) and washing the cells five times with the same buffer by centrifugation at $400 \mathrm{~g}$ to remove erythrocytes as previously described [11].

\section{Fluorescence Labeling}

Whole cells were stained with an indirect immunofluorescence procedure. Cells were harvested and washed 8 days after intraperitoneal inoculation into mice as described above. Approximately $10^{5}$ fresh cells were placed in $0.5 \mathrm{ml}$ of a $0.05 \mathrm{M}$ phosphate buffer ( $\mathrm{pH} 7.4$ ) containing $0.85 \% \mathrm{w} / \mathrm{v} \mathrm{NaCl}$ (PBS). Unconjugated rabbit antisera at a dilution of $1: 8$ was added to the cell suspension and incubated for $30 \mathrm{~min}$ at either $4^{\circ} \mathrm{C}$ or $37^{\circ} \mathrm{C}$. The cells were washed two times at $4^{\circ} \mathrm{C}$ and rinsed in PBS buffer for $1 \mathrm{~h}$ at $4^{\circ} \mathrm{C}$. The washed cells were resuspended in PBS buffer and incubated for $30 \mathrm{~min}$ at $4^{\circ} \mathrm{C}$ with fluorescein-conjugated goat anti-rabbit-IgG serum (Miles-Yeda, Ltd). The fluorescent-labeled goat antiserum was clarified by centrifugation at $48,000 \mathrm{~g}$ for $5 \mathrm{~min}$ immediately before use. The stained cells were washed two times in PBS buffer and then rinsed in PBS buffer for $1 \mathrm{~h}$ at $4^{\circ} \mathrm{C}$. After

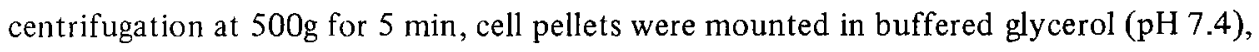
under cover slips sealed with fingernail polish and observed by fluorescence microscopy.

Preparation of cell coat fraction and coat particle. The cell coat fraction was prepared by incubation of whole cells in isotonic buffer for $1 \mathrm{~h}$ and collection of the supernatant fraction after centrifugation at $48,000 \mathrm{~g}$ [10] as shown in Scheme 1. All steps were performed at $4^{\circ} \mathrm{C}$ to minimize metabolic and proteolytic activity. The cells were harvested 


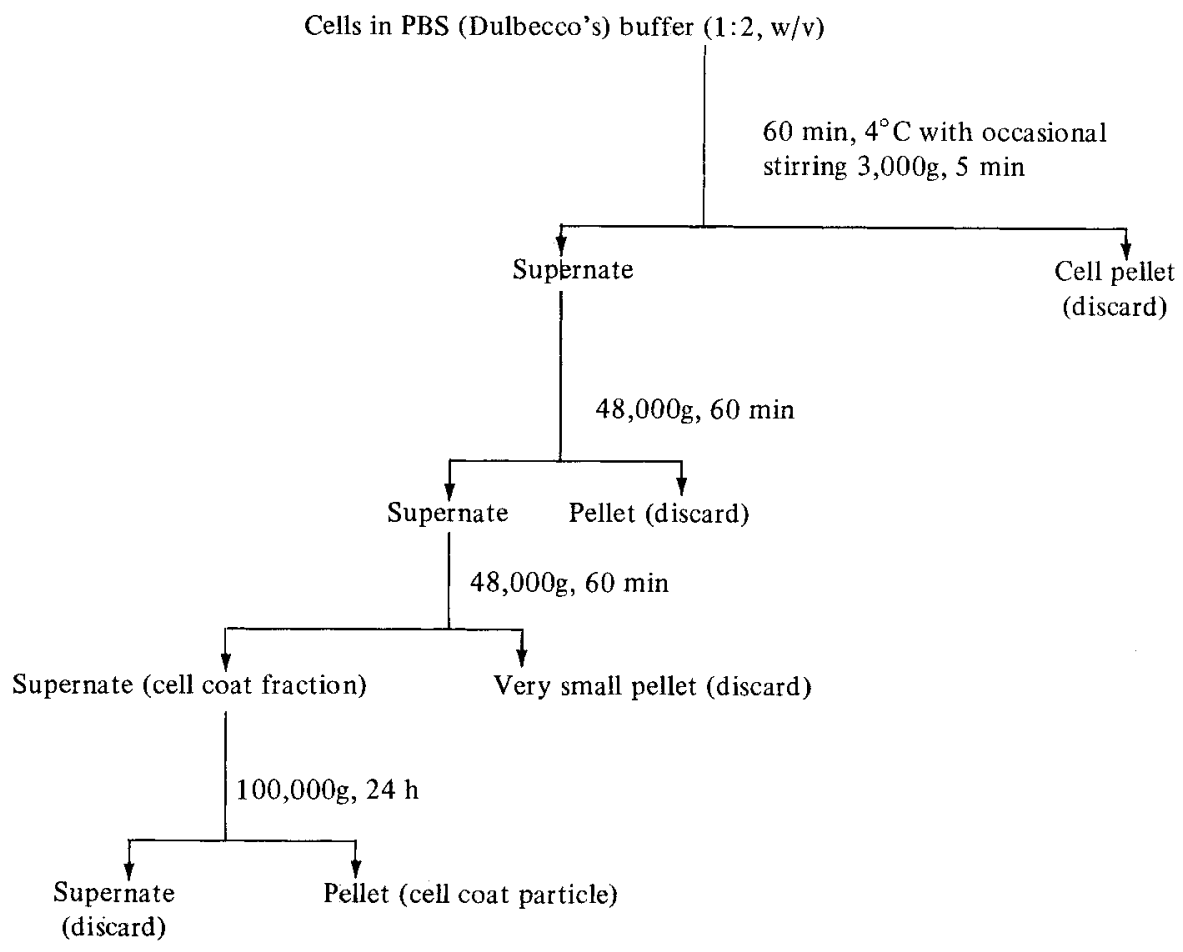

Scheme I. Isolation of cell coat fraction and cell coat particle from Ehrlich ascites tumor cells.

from mice 8-9 days after inoculation and washed five times immediately before use. Greater than $92 \%$ of the cells were found to be viable after removal of the cell coat fraction as revealed by the Trypan-blue staining method.

The cell coat particle was collected as the pellet after ultracentrifugation of fresh cell coat fraction at $100,000 \mathrm{~g}$ for $24 \mathrm{~h}$ (Scheme 1).

Chemical determinations. Protein content was measured by the method of Lowry et al [17] employing bovine serum albumin (Sigma Chemicals) as a standard.

Preparation of plasma membrane. Plasma membranes were prepared by density gradient centrifugation of Ehrlich cell homogenates according to the method of Im et al [12] as previously described [10].

Immunochemical studies. Immunodiffusion and immunoelectrophoresis were performed on microscope slides measuring $75 \times 50 \mathrm{~mm}$ in $1.0 \%$ agarose (Type II, Sigma Chemicals in barbital buffer, pH $8.4(\mu=0.040)$.

Precipitation of cell coat components with rabbit anti-mouse immunoglobulin $\mathrm{G}$ (Miles-Yeda) was carried out by immunodiffusion in 1\% agarose slides in PBS (pH 7.0) containing $0.1 \%$ Triton $\mathrm{X}-100$ and $1 \mathrm{M}$ urea; these conditions dissociate protein aggregates while allowing antibody-antigen precipitation [13]. The cell coat particle, $5 \mathrm{mg}$ of protein, was radiolabeled by reductive alkylation using $50 \mu \mathrm{Ci}$ of ${ }^{14} \mathrm{C}$-formaldehyde $(10 \mathrm{mCi} / \mathrm{mmole}$, New England Nuclear) [14]. The radiolabeled cell coat particles were placed in wells containing unlabeled cell coat particle antigens as carrier, and double-diffusion against rabbit anti-mouse IgG was allowed to proceed at $4^{\circ} \mathrm{C}$ for $72 \mathrm{~h}$. Immune precipitates were 
sliced from gels and washed extensively, and the precipitated antigens were released by incubation in a solution of $2 \%$ sodium dodecyl sulfate (SDS) and $0.1 \% 2$-mercaptoethanol for gel electrophoresis studies.

Production of antisera. Antiserum to the cell coat fraction of Ehrlich ascites tumor cells (anti-cc) was prepared by subcutaneous injection of cell coat fraction into each of two rabbits. Approximately $5-10 \mathrm{mg}$ protein was injected in incomplete Freund's adjuvant (Grand Island Biological Co) twice weekly for 10 weeks. It was found that antisera of significantly higher titer could be produced by adding the plant lectin concanavalin $\mathrm{A}$ ( $1 \mathrm{mg}$ lectin per milligram cell coat fraction protein) and subcutaneous injection of the glycoprotein-lectin mixture in the presence of incomplete Freund's adjuvant. Concanavalin A was prepared from jack bean meal (Signa) by the method of Agrawal and Goldstein [15] .

Antiserum to a $45,000 \mathrm{MW}$ component of the cell coat fraction (anti-45) was prepared in the following manner. Approximately $10 \mathrm{mg}$ of cell coat fraction protein was electrophoresed on sodium dodecyl sulfate-polyacrylamide gels (SDS-PAGE) with a Hoefer 10- $\times 14-\mathrm{cm}$ slab gel apparatus (Hoefer Scientific Instruments). Electrophoresis was performed by the method of Laemmli [16] using a $4 \%$ acrylamide stacking gel and a $7.5 \%$ acrylamide separating gel. Slab gels were fixed in a $7 \%$ acetic acid-50\% methanol solution and stained with Coomassie Blue. The stained protein band at an approximate molecular weight position on the gel of 45,000 (Fig. I) was cut from the gel, minced with a razor blade, and homogenized with a Dounce homogenizer. The homogenized gel was mixed with Freund's incomplete adjuvant and injected subcutaneously into rabbits. Each rabbit was injected with the homogenized material from one complete slab gel. Elution of protein from one of these slab gel preparations with $2 \%$ SDS in PBS revealed $400-600 \mu \mathrm{g}$ of protein by the method of Lowry et al [17]. Rabbits received injections every 4-5 days. Employing the above immunization protocol, one rabbit produced precipitating antibodies by day 54 and a second rabbit by day 82 as determined by immunodiffusion analysis.

Absorption of antisera. Antisera were exhaustively absorbed with intact Ehrlich ascites tumor cells in order to remove specific antibodies to cell surface antigens. Antiserum $(1.0 \mathrm{ml})$ was incubated with $1.0 \mathrm{ml}$ of packed, fresh Ehrlich cells $\left(4.5 \times 10^{8}\right.$ cells $)$ for 30 min at room temperature followed by incubation at $4^{\circ} \mathrm{C}$ for $\mathrm{h}$ with occasional mixing. The cells were centrifuged at $500 \mathrm{~g}$ for $10 \mathrm{~min}$. The supernate was absorbed three more times against $1.0 \mathrm{ml}$ of fresh Ehrlich cells in the same manner. The final supernate was concentrated to the original serum volume $(1.0 \mathrm{ml})$ in a Minicon-B1 5 concentrator (Amicon Corp). A control experiment in which goat anti-rabbit IgG (Miles Laburatories) was absorbed with Ehrlich cells in the same manner did not eliminate precipitating antibodies to rabbit serum after immunodiffusion analysis.

\section{RESULTS}

\section{Sedimentation of a Cell Coat Particle Released From Cells With Isotonic Buffer}

Incubation of ascites tumor cells with isotonic buffer for $1 \mathrm{~h}$ at $4^{\circ} \mathrm{C}$ followed by two successive centrifugation steps $(48,000 \mathrm{~g}$ for $1 \mathrm{~h})$ resulted in a "soluble" preparation of cell surface material referred to as the cell coat fraction, as shown in Scheme 1. However, less than $20 \%$ of the total protein of this "soluble" cell coat fraction penetrates an XM 300 membrane (Amicon) during ultrafiltration (Table I), suggesting the presence of highmolecular-weight aggregates or possibly small membrane vesicles. In order to test this possibility, the cell coat fraction was subjected to ultracentrifugation at $100,000 \mathrm{~g}$ for $24 \mathrm{~h}$. A gelatinous material representing about $30 \%$ of the total protein was pelleted by this procedure and is referred to as the "cell coat particle." 


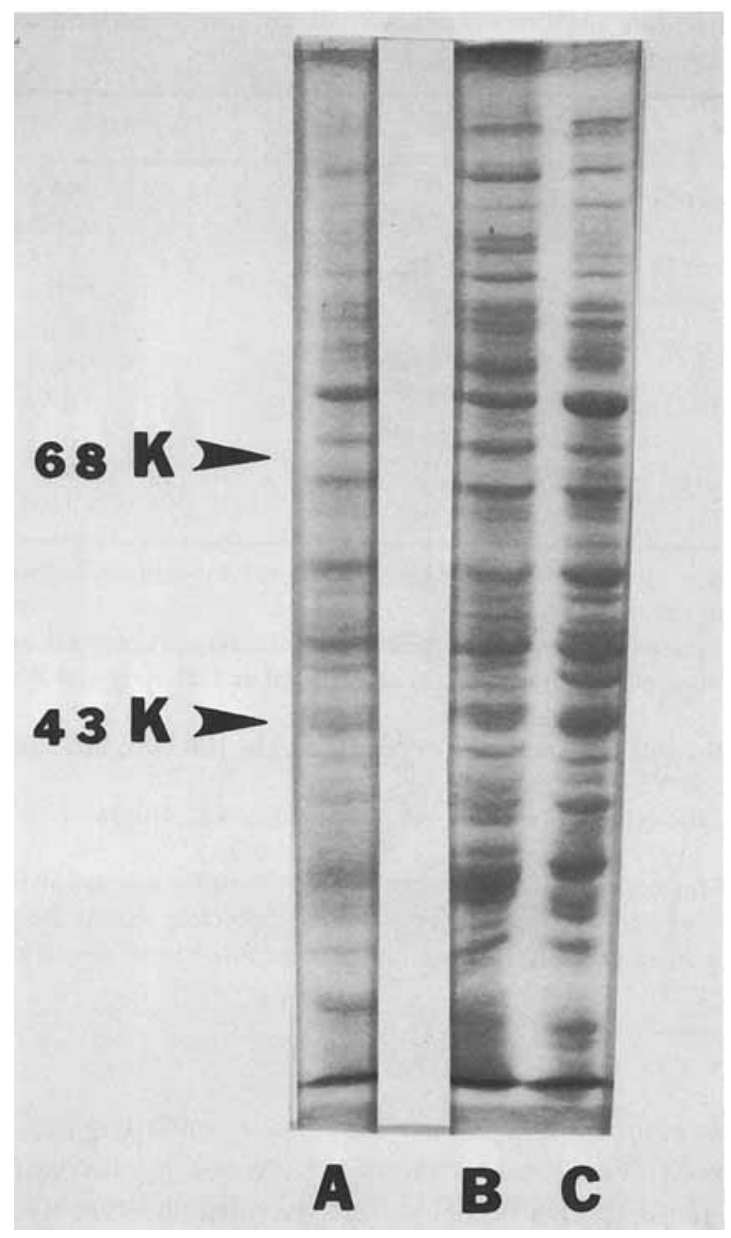

Fig. 1. Analysis of cell coat particle released from Elurlich ascites tumor cells with isotonic buffer. The cell coat particle was collected as a pellet after ultracentrifugation of the cell coat fraction at $100,000 \mathrm{~g}$ for $24 \mathrm{~h}$. Samples were subjected to gel clectrophoresis in the presence of sodium dodecyl sulfate on slab polyacrylamide gels (SDS-PAGE) according to the method of Laemmli [16]. The separating gel contained $10 \%$ acrylamide, $0.2 \%$ methylenebisacrylamide and $0.1 \%$ SDS in the Tris-HCl system at $\mathrm{pH}$ 8.8. The stacking gels contained $4 \%$ acrylamide. The samples were dialyzed against sample butfer containing 0.1 . 2 -mercaptoethanol and heated at $100^{\circ} \mathrm{C}$ for $5 \mathrm{~min}$ before electrophoresis. Electrophoresis was performed at room temperature at $20 \mathrm{~mA} / \mathrm{gel}$ for $4-5 \mathrm{~h}$. Proteins were detected by staining with a Coomassie blue-perchloric acid solution [18) after fixation. Molecular weight markers were: $\beta$-galactosidase $(130,000)$, bovine serum albumin $(68,000)$, ovalbumin $(43,000)$, pepsin $(35,000)$. trypsin $(23,400)$, and cytochrome C. $(11,700)$ run in parallel with the samples on the same slab gel. A) Cell coat fraction, $5 \mu \mathrm{g}$ protein; B) cell coat particle, $5 \mu \mathrm{g}$ protein; C) supernatant traction (concentrated 25-fold in a Minicon-B 15 concentrator, Amicon Corp) after ultracentrifugation of cell coat fraction at $100,000 \mathrm{~g}$ for $24 \mathrm{~h}, 5 \mu \mathrm{g}$ protein.

In contrast, shorter periods of ultracentrifugation of the cell coat fraction $(100,000 \mathrm{~g}$ for $2 \mathrm{~h}$ ) failed to pellet more than $1 \%$ of the total protein, indicating that large membrane fragments were absent (Table I). Also, a time-dependent aggregation of components is apparently ruled out by the finding that incubation of the cell coat fraction at $4^{\circ} \mathrm{C}$ for $24 \mathrm{~h}$ followed by ultracentrifugation at $100,000 \mathrm{~g}$ for 2 min resulted in less than $1 \%$ of pelleted material (Table I). 
TABLE I. Ultracentrifugation and Ultrafiltration Studies of Components Spontaneously Released From Ehrlich Ascites Tumor Cells in Vitro

\begin{tabular}{lc}
\hline \multicolumn{1}{c}{ Fraction } & \% Protein of total \\
\hline 1. $48,000 \mathrm{~g}$ Supernate $($ cell coat fraction) \\
Pellet & 99.4 \\
2. $100,000 \mathrm{~g}$ Supernate $(24 \mathrm{~h})^{\mathrm{c}}$ & $<0.6$ \\
Pellet (cell coat particle) & 69.5 \\
3. 100,000g Supernate $(2 \mathrm{~h})^{\mathrm{d}}$ & 30.4 \\
Pellet & 96.4 \\
4. 100,000g Supernate $(24-\mathrm{h}$ incubation) & 0.7 \\
Pellet & 99.7 \\
5. Retentate & $<0.3$ \\
Eluate & 84.0 \\
\hline
\end{tabular}

\footnotetext{
a Protein was determined by the method of Lowry et al [17] for samples before (total protein) and after ultracentrifugation or ultrafiltration.

bSupernate and pellet fractions obtained in the cell coat fraction preparation as described in Scheme 1.

cFor $24 \mathrm{~h}, 5.8 \mathrm{mg}$ of the cell coat fraction was centrifuged at $100,000 \mathrm{~g}$ and the supernate and pellet were collected.

$\mathrm{d}_{\text {For }} 2 \mathrm{~h}, 18.3 \mathrm{mg}$ of the cell coat fraction was centrifuged at $100,000 \mathrm{~g}$ and the superante and pellet were collected.

eFor $24 \mathrm{~h} 18.5 \mathrm{mg}$ of the cell coat fraction was incubated at $4^{\circ} \mathrm{C}$, followed by ultracentrifugation at $100,000 \mathrm{~g}$ for $2 \mathrm{~min}$.

${ }^{\mathrm{f}}$ A 2.6-mg portion of the cell coat fraction in $30 \mathrm{ml}$ of PBS buffer was applied to an Amicon stirred cell containing a XM 300 ultrafilter membrane (nominal molecular weight "cut-off" $>300,000$ ). The protein solution was concentrated 20 -fold and the protein contents of the retentate and eluate were determined.
}

SDS gel electrophoresis analysis revealed that essentially all of the polypeptide species present in the cell coat fraction were present in the cell coat particle (Fig. 1). A very similar if not identical SDS-PAGE pattern was also observed with the supernatant portion obtained after ultracentrifugation, although the staining intensity of proteins greater than $70,000 \mathrm{MW}$ was noticeably reduced (Fig. 1).

\section{Immunodiffusion and Immunoelelctrophoresis Analysis of Spontaneously Released Cell Coat Material}

Rabbit anti-mouse immunoglobulin $\mathrm{G}$ gave a single precipitin band after double diffusion against the cell coat particle (Fig. 2). A slight spur reaction resulted in the precipitin band of the cell coat fraction with the compared mouse IgG (Fig. 2). Anti-mouse IgG did not react with purified plasma membrane (Fig. 2). Anti-rat complement C3 (Cappel Laboratories) gave a weak precipitin reaction with the cell coat particle (not shown). Antiserum raised in rabbits against the cell coat fraction (anti-cc) gave precipitin lines with both cell coat fraction and purified plasma membranes from ascites tumor cells after double diffusion in 1\% agarose (not shown). Antiserum prepared against an isolated 45,000 MW component(s) of the cell coat fraction gave a single sharp precipitin line against cell coat fraction and purified plasma membrane after agarose double-diffusion analysis (not shown).

Immunoelectrophoresis analysis of antiserum versus the cell coat fraction (anti-cc) revealed two major antibody-antigen precipitin arcs located toward the anode (Fig. 3). On the other hand, antiserum to the $45 \mathrm{k}$ component(s) produced a single sharp precipitin arc located toward the cathode (Fig. 3). 


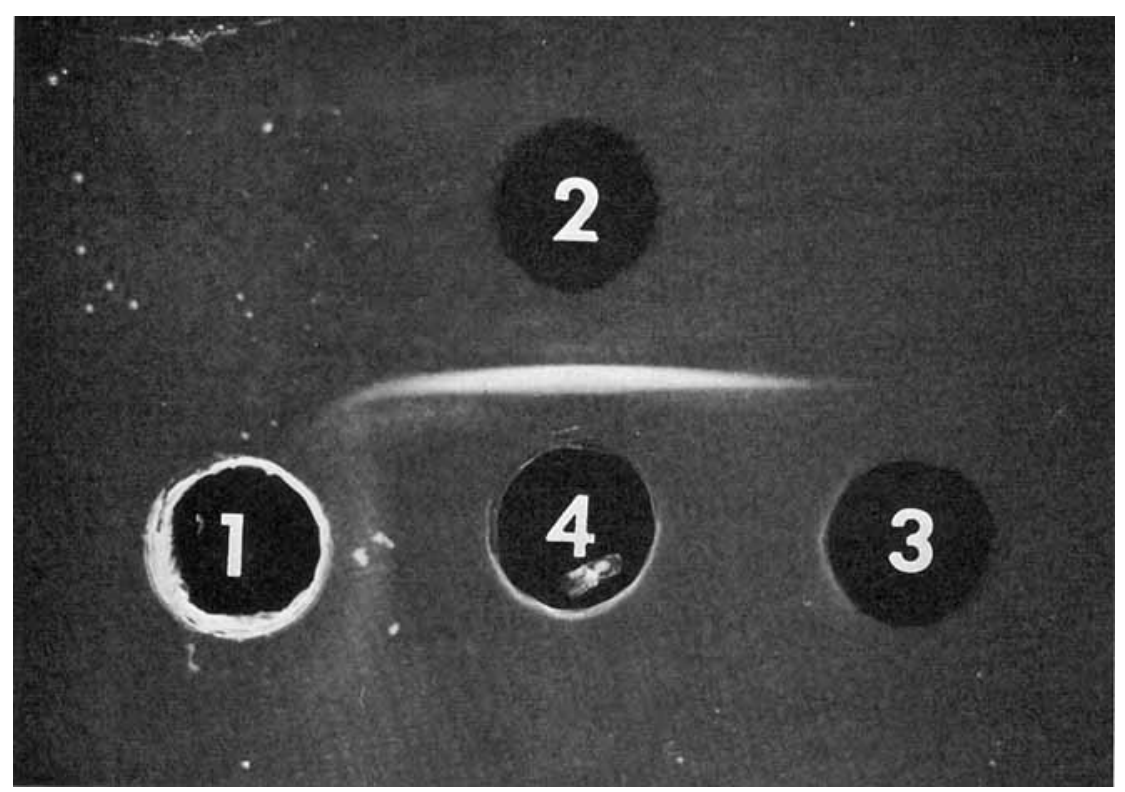

Fig. 2. Immunodiffusion study of antisera to mouse IgG: Well 1) cell coat particle prepared as described in Methods; Well 2) mouse immunoglobulin G2a (MOPC); Well 3) purified plasma membrane prepared as described in Methods; Well 4) IgG fraction of rabbit anti-mouse IgG serum (Miles-Yeda Ltd).
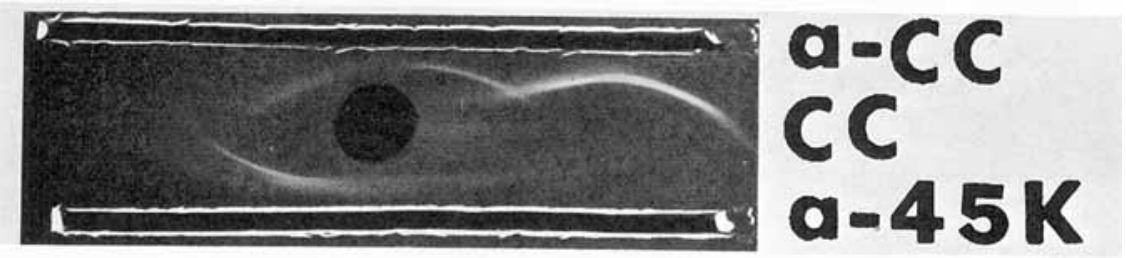

Fig. 3. Immunoelectrophoresis analysis of antiserum to cell coat fraction from Ehrlich tumor cells (anti-cc) and antiserum to a MW 45,000 component of the cell coat fraction (anti-45k). Electrophoresis was performed for $1.5 \mathrm{~h}$ at $20 \mathrm{~mA}$ per slide in $0.05 \mathrm{M}$ barbital buffer $(\mathrm{pH} \mathrm{8.4)}$. Upper and lower troughs contained anti-cc (a-cc) and anti-45k (a-45k) sera, respectively. The center well contained cell coat fraction (cc). The anode is to the right. Complete immune precipitation required $72 \mathrm{~h}$ at $4^{\circ} \mathrm{C}$.

\section{Surface Staining of Ehrlich Ascites Tumor Cells}

Figure $4 \mathrm{~A}$ shows the results obtained with the indirect membrane immunofluorescence method at $4^{\circ} \mathrm{C}$ using rabbit anti-mouse immunoglobulin $\mathrm{G}$ serum. It is apparent that there is a clear difference in the staining of cells with the antiserum compared with control serum (Fig. 4A). A larger magnification (Fig. 4B) revealed that the tumor-associated IgG of Ehrlich ascites tumor cells is localized on the cell surface in a very heterogeneous manner. Stained cells exhibited a variety of fluorescence patterns including full surface fluorescence, a speckled appearance with numerous small aggregates, larger aggregates in patches, and localization at the poles of cells in caps (Fig. 4B). Incubation of tumor cells with antimouse IgG for $1 \mathrm{~h}$ at $37^{\circ} \mathrm{C}$ prior to fluorescent staining appreciably increased the number of cells exhibiting a patch or cap fluorescent pattern (not shown). Examination of cells 

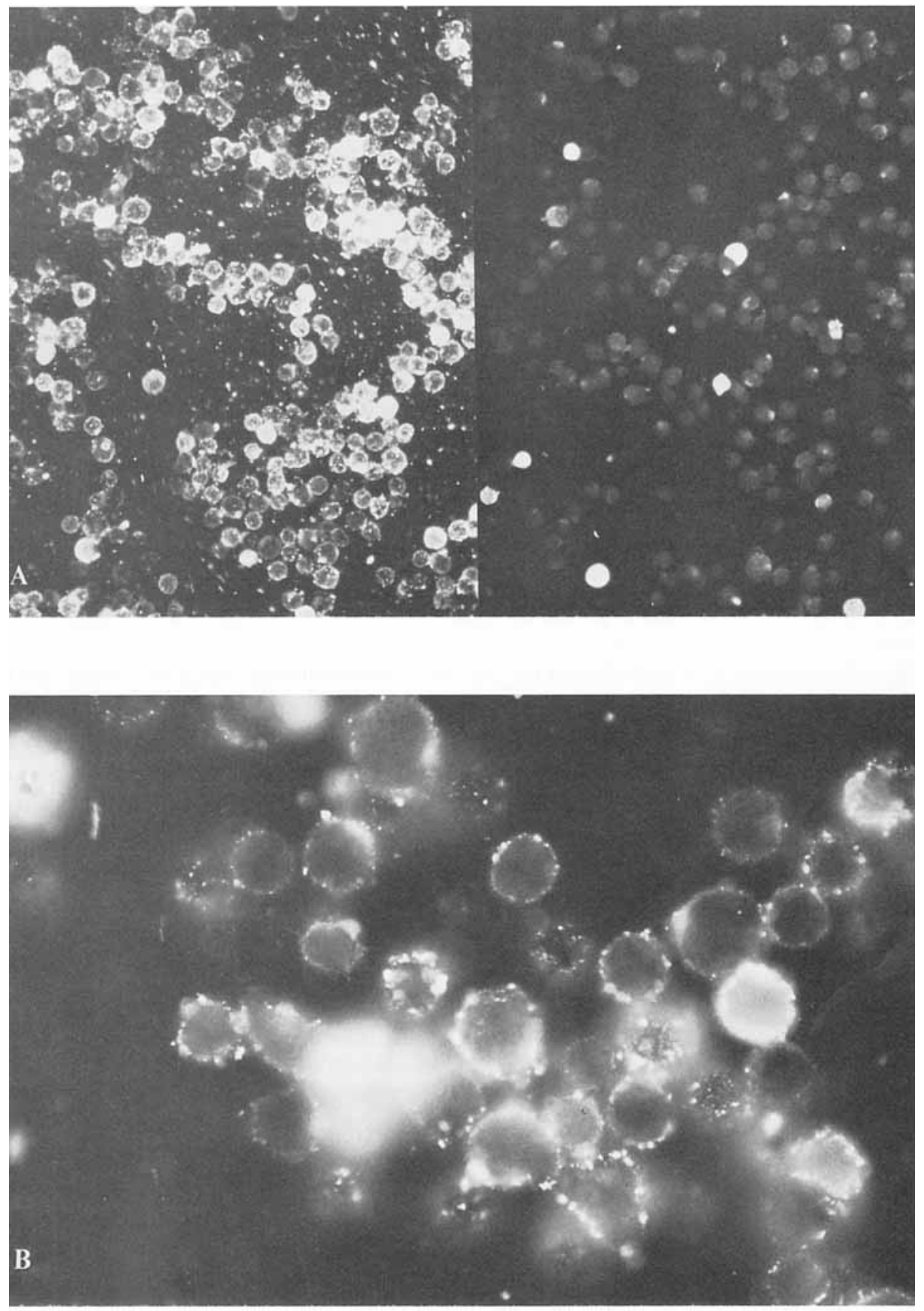

Fig. 4. Immunofluorescence of cell surface antigens. All steps were performed at $4^{\circ} \mathrm{C}$. Cells were harvested in PBS buffer ( $\mathrm{pH} 7.4$ ) eight days after inoculation, washed five times, and used immediately for fluorescence studies. Approximately $10^{5}$ cells were incubated with a $1: 8$ dilution of either immune or preimmune (control) rabbit serum, for $30 \mathrm{~min}$, washed two times in PBS and rinsed in PBS for 60 $\min$. The cells were then stained by incubation with fluorescein-labeled goat antiserum to rabbit IgG for $30 \mathrm{~min}$, washed two times in PBS, and rinsed in PBS for $60 \mathrm{~min}$. The cells were then collected as pellets by centrifugation at $500 \mathrm{~g}$ for $5 \mathrm{~min}$ and mounted in buffered glycerol (pH 7.4) under coverslips 

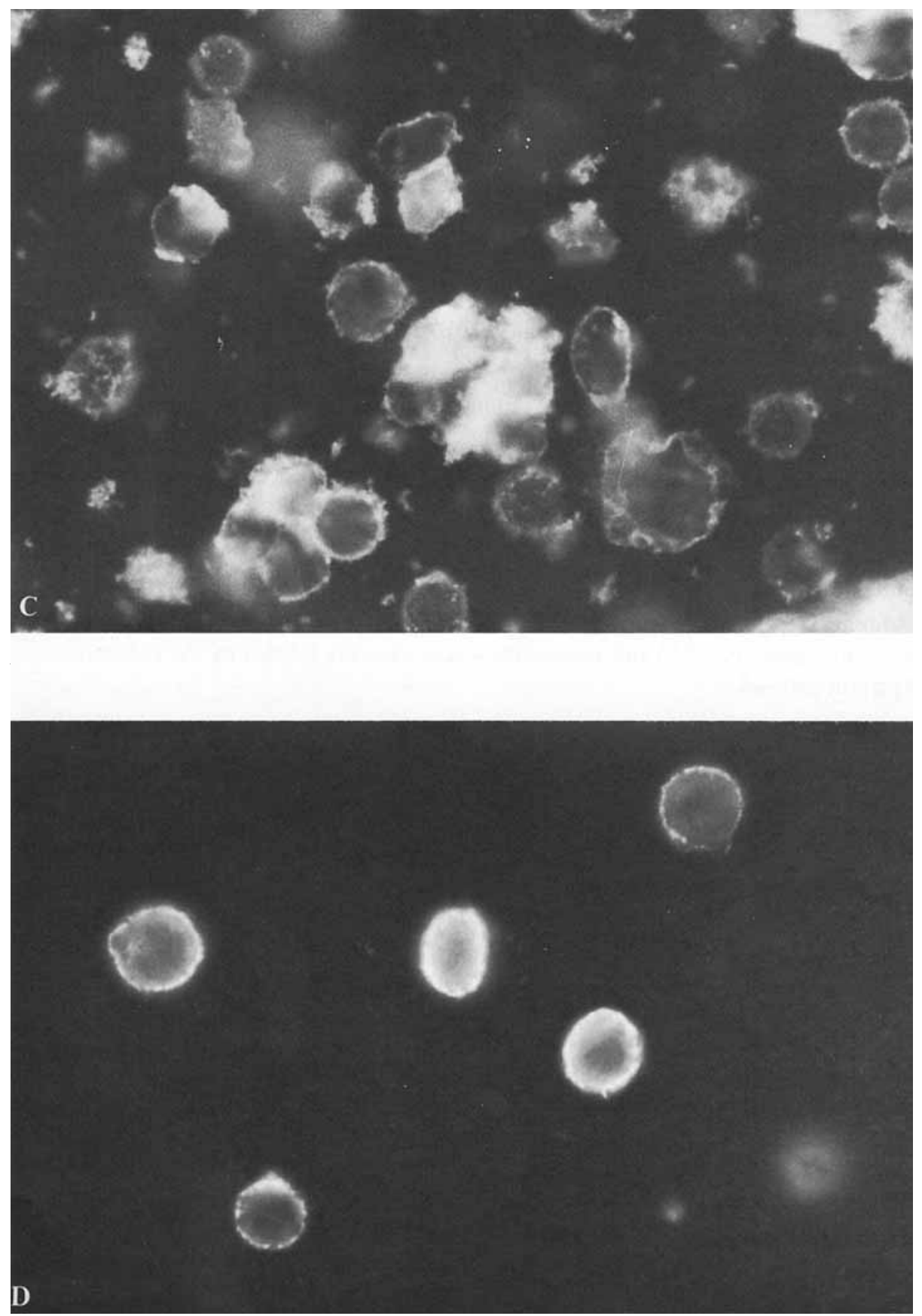

sealed with fingernail polish on microscope slides. The cells were photographed with a Zeiss ultraviolet microscope III, with a dark-field condenser and BG-38 and barrier 530 filters using a mercury arc lamp as a light source. Photographs were taken on Kodak Tri-X film. Cells incubated with A, left side) rabbit anti-mouse IgG serum (Miles-Yeda); A, right side) preimmune (control) rabbit serum $\times 190$; B) rabbit anti-mouse IgG serum ( $\times 800)$; C) rabbit anti-serum to the cell coat fraction (anti-cc) $(\times 800)$; (D) rabbit antiserum to a $45,000 \mathrm{MW}$ component of the cell coat fraction (anti-45k) ( $\times 800)$. 
stained with anti-cc serum also revealed a very heterogeneous fluorescence pattern (Fig. 4C).

Note that some cells show a diffuse staining over the whole surface, while other cells exhibit either a patchy appearance or cap fluorescence (Fig. 4C). In addition some cells are not appreciably stained at all (Fig. 4C). It was often observed that fluorescence staining was extremely prominent in regions of cell-to-cell contact (Fig. 4C). In contrast, fluorescence staining with the anti-45k serum resulted in a majority of cells exhibiting a full surface or ring fluorescence. The surface specificities of the antisera to cell coat components was confirmed by exhaustive absorption tests. Absorption of either anti-cc or anti-45k antiserum with whole Ehrlich cells completely eliminated reaction with cells as observed by indirect immunofluorescence (not shown).

\section{Gel Electrophoresis Analysis of Immune-Precipitated Components of the Cell Coat Particle}

Detergent gel electrophoresis of immune precipitates obtained from agarose double diffusion of radiolabeled cell coat particle with anti-mouse IgG followed by autoradiography revealed approximately seven major polypeptides ranging in molecular weight from 30,000 to more than 100,000 (Fig. 5B). Very little background was observed in this procedure, as shown by autoradiography after electrophoresis of the solubilized immune precipitate obtained with radiolabeled mouse serum and rabbit anti-mouse IgG (Fig. 5A). Only two bands at 50,000 and 25,000 MW representing heavy and light chains of immunoglobulin $\mathrm{G}$ respectively were present (Fig. 5A). The light chain was only faintly visible by autoradiography (Fig. 5A) and apparently was not heavily labeled by the reductive alkylation method.

\section{DISCUSSION}

Both the ultrafiltration and ultracentrifugation data (Fig. 1 and Table I) indicate that the cell coat components of Ehrlich ascites tumor cells are shed as a macromolecular complex or "cell coat particle." Membrane immunofluorescence at $4{ }^{\circ} \mathrm{C}$ with rabbit antisera raised against the cell coat fraction revealed a strikingly nonuniform staining pattern (Fig. 4). A small percentage of the cells exhibited full surface fluorescence, while many more cells contained fluorescent stain in a highly patched or capped pattern. In addition, some cells contained little or no stain, indicating that the cell surface antigens or antibodyantigen complexes were completely released from these cells during growth in vivo or during the time course of the fluorescent staining procedure. It should be noted that the patched and capped appearance of the fluorescent-stained cells was observed at $4^{\circ} \mathrm{C}$; these conditions are considered to greatly retard surface antigen mobility and inhibit redistribution of surface antigens on the cell surface [19]. It is possible that these cell surface components have already undergone extensive redistribution during growth in vivo due to binding of host antibodies at the cell surface. A highly aggregated arrangement of antibodyantigen complexes at the cell surface may explain the facile release of these components into cold isotonic buffer.

If host immune components induce the redistribution and release of tumor cell glycoproteins from the cell surface, immune components should a) be present on the tumor cell surface b) spontaneously shed from cells into extracellular fluids, and c) bind tightly to specific tumor cell surface componénts. There is considerable precedent for this possibility, since humoral immune components have been detected on the surface of a wide variety of malignant tumors [20]. In particular, the association of immunoglobulins with the tumor cell surface has been demonstrated by a number of techniques including radio- 


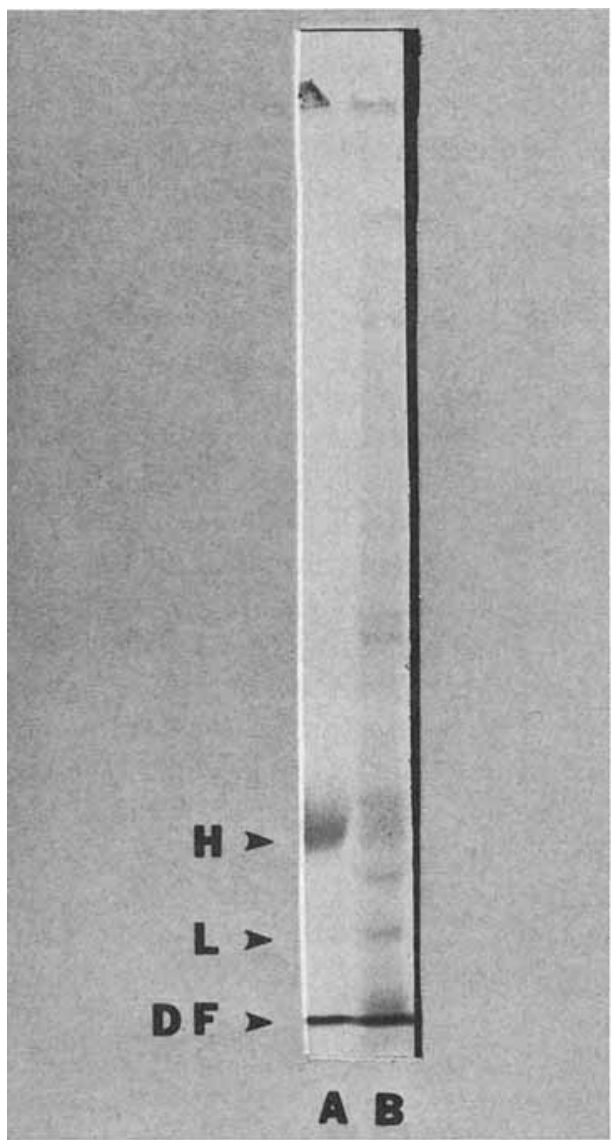

Fig. 5. Analysis of cell coat particle components precipitated with anti-mouse IgG serum. The cell coat particle was prepared from Ehrlich ascites tumor cells and labeled with ${ }^{14} \mathrm{CHO}$ by reductive alkylation [14], as described in Methods. Immune precipitates were obtained in 1\% agarose gels after double diffusion of radiolabeled cell coat particle (unlabeled cell coat particle was added as a carrier) and rabbit anti-mouse IgG serum (Miles-Yeda). The immune precipitates were allowed to develop for $72 \mathrm{~h}$ at $4^{\circ} \mathrm{C}$. The gel portion containing the immune precipitate bands was resected from the agarose slide and incubated in PBS buffer for $48 \mathrm{~h}$ with at least three changes of buffer to remove comigrating soluble proteins. The agarose strips containing the immune precipitate were then minced with a Dounce homogenizer and washed five times in PBS buffer by centrifugation at 20;000g and resuspension in PBS each time. The antigens and antibodies were released from the immune precipitate by incubation of the final homogenized pellet in a small volume of SDS-PAGE sample buffer containing $2 \%$ SDS and $0.1 \% 2$-mercaptoethanol for $12 \mathrm{~h}$ at $4^{\circ} \mathrm{C}$, followed by incubation for $1 \mathrm{~h}$ at $50^{\circ} \mathrm{C}$. The sample was centrifuged at $48,000 \mathrm{~g}$ for $10 \mathrm{~min}$ and the supernatant portion was collected and treated at $100^{\circ} \mathrm{C}$ for $5 \mathrm{~min}$ before electrophoresis. SDS-PAGE was performed on $7.5 \%$ acrylamide gels by the method of Laemmli [16], as described in the legend to Figure 1. The autoradiograph represents A) immune precipitate obtained from radiolabeled mouse serum and anti-mouse IgG, about $5,000 \mathrm{cpm}$; B) cell coat components precipitated with anti-mouse IgG, about $20,000 \mathrm{cpm}$. H, L, DF (arrows, left) mark positions of immunoglobulin heavy and light chains and dye marker respectively.

immunofixation [21] and membrane immunofluorescence [22]. The important question whether tumor-associated immunoglobulin (TAIg) represents antitumor antibodies remains largely unanswered. In the present study we employed membrane immunofluorescence to demonstrate that IgG is present on the surface of Ehrlich ascites tumor cells (Fig. 4). The distribution of IgG on the tumor cell surface was very heterogeneous, with 
considerable patches and caps of fluorescent stain present on the cells (Fig. 4), suggesting a possible antibody-induced redistribution of cell surface antigens in vivo.

Immunodiffusion studies demonstrated that IgG bound to the surface of Ehrlich ascites tumor cells was spontaneously released from cells with isotonic buffer (Fig. 2). Ultracentrifugation and ultrafiltration experiments indicated that the $\operatorname{IgG}$ which is shed from the cell surface is present as a high-molecular-weight aggregate (Fig. 1 and Table I). The additional presence of a complement component (C3) in the cell coat particle is consistent with the possibility that this high-molecular-weight complex is composed at least in part of humoral immune components bound to the tumor cell surface.

In order to determine whether tumor-associated $\operatorname{lgG}$ is tightly bound to other protein(s) in the cell coat particle, we employed an immunoprecipitation-detergent gel electrophoresis autoradiography procedure. The immune precipitation was carried out in the presence of $0.1 \%$ Triton $\mathrm{X}-100$ and $1 \mathrm{M}$ urea in order to minimize protein-protein aggregation while permitting specific immune components including IgG and complement to remain bound to antigen(s). These studies revealed that multiple components are tightly bound to TAIg in the cell coat particle (Fig. 5). The components which bind TAIg could represent tumor cell antigen(s) and host complement components bound at the cell surface to antibodies directed against the tumor. However, the possibility that some proteins remained nonspecifically bound to IgG under these conditions and accounted for the proteins coprecipitated with anti-mouse IgG cannot be ruled out at this time.

It seems unlikely that IgG present in the cell coat particle represents binding to $\mathrm{Fc}$ receptors, since monomeric IgG binds with a relatively low affinity to Fc receptors and is released from cells by washing [23]. It is possible, however, that immune complexes unrelated to the host response to the tumor could be present in the host body fluids and bind with high affinity to $F c$ receptors on the tumor cell surface $[23,24]$. In this regard it should be noted that Braslawsky et al [24] have demonstrated that antibodies unrelated to tumor cell antigens can bind tumor cells and constitute at least a part of the total TAIg.

In order to gain a better understanding of the origin of the material spontaneously shed by tumor cells, we are currently employing metabolic labeling of tumor cells in vivo followed by isolation of the cell coat particle containing the putative immune complexes. Tumor cell-derived components, which are tightly bound to TAIg, can then be identified by precipitation with ant i-IgG followed by gel electrophoresis and autoradiography.

\section{ACKNOWLEDGMENTS}

This work was supported by Michigan Memorial Phoenix Project 510 No. 361451 and USPHS S-07 RR 05383.

\section{REFERENCES}

I. Hellstrom K, Hellstrom I: Adv Immunol 18:209, 1974.

2. Baldwin RW: Transplant Rev 28:62, 1976.

3. Ting C-C, Herberman RB: Int Rev Exp Pathol 15:94, 1976.

4. Nepom JT, Hellstrom I, Hellstrom KE: Proc Natl Aaad Sci USA 74:4605, 1977.

5. Thomson DP, Steele K, Alexander P: Br J Cancer 27:27, 1973.

6. Sjogren HO, Hellstrom I, Bansal SC, Warner GA, Hellstrom KE: Int J Cancer 9:274, 1972.

7. Baldwin RW, Bowen JG, Price MR: Br J Cancer 28:16, 1973.

8. Grimm EA, Silver HKB, Roth JA, Chee DO, Gupta RK, Morton D: Int J Cancer 17:559, 1976.

9. Stulilmiller GM, Seigler HF: J Natl Cancer Inst 58:215, 1977.

10. Rittenhouse HG, Rittenhouse JW, Takemoto L: Biochemistry 17:829, 1978. 
11. Rittenhouse HG, Benian GM, Rittenhouse JW, Hansen ER, Boyd LE: Prog Clin Biol Res 9:203, 1976.

12. Im WB, Christensen HN, Sportes B: Biochem Biophys Acta 436:424, 1976.

13. Rittenhouse HG, Heptinstall J, McFadden BA: Biochemistry 10:4045, 1971.

14. Rice RH, Means GE: J Biol Chem 246:831, 1971.

15. Agrawal BBL, Goldstein IJ: Methods Enzymol 288:313, 1972.

16. Laemmli UK: Nature (London) 227:680, 1970.

17. Lowry OH, Rosebrough NJ, Farr AL, Randall RJ: J Biol Chem 193:265, 1951.

18. Holbrook IB, Leaver AG: Anal Biochem 75:634, 1976.

19. Frye CD, Edidin M: J Cell Sci 7:313, 1970.

20. Witz IP: Adv Cancer Res 25:95, 1977.

21. Witz IP, Kinamon S, Rau M, Klein G: Clin Exp Immunol 16:321, 1974.

22. Isa AM, Sanders BR: Transplantation 20:296, 1975.

23. Segal DM, Hurwitz E: J Immunol 118:1338, 1977.

24. Braslawsky GR, Serban D, Witz IP: Eur J Immunol 6:579, 1976. 